\title{
Kasus Kontrol Hubungan Imunisasi BCG dengan kejadian TB Paru pada anak tahun 2015-2016
}

\author{
R. Evi Sofia Riani, Putri Bungsu Machmud* \\ Staf Dinas Kesehatan Kota Sukabumi, "Staf pengajar Departemen Epidemiologi FKM-UI, Kampus UI Depok
}

Latar belakang. Tuberkulosis adalah penyakit yang masih menjadi masalah kesehatan di dunia. Pada tahun 2014 terjadi peningkatan insidens, prevalens bahkan kematian karena TB di Indonesia.

Tujuan. Mengetahui besar risiko tidak diimunisasi BCG terhadap kejadian TB Paru pada anak di Kota Sukabumi tahun $2015-2016$ setelah dikontrol oleh variabel umur, jenis kelamin, berat badan lahir, pemberian ASI Eksklusif, kunjungan Neonatal, pemberian Vitamin A, pendidikan Ibu dan Pekerjaan Ibu. Sedangkan tujuan sekunder dari studi ini adalah mengidentifikasi status imunisasi BCG dan kejadian TB Paru pada anak serta variable covariatnya dan mengetahui besar risiko anak yang tidak diimunisasi serta mengetahui besar Efektivitas vaksin BCG.

Metode. Penelitian ini menggunakan desain case control. Kasus dan kontrol adalah anak kota Sukabumi usia 0-5 tahun yang diperoleh dari laporan rutin program TB, imunisasi, KIA dan Gizi di Dinas Kesehatan Kota Sukabumi.

Hasil. Analisis multivariat menunjukkan bahwa risiko anak yang tidak diimunisasi BCG dan KN sebanyak 3 kali adalah 1,13 kali lebih besar untuk terkena TB paru dibandingkan kelompok rujukan dan anak yang diimunisasi BCG. Dari hasil tersebut diketahui bahwa efektivitas vaksin BCG tanpa interaksi 67\%, sedangkan dengan interaksi $82 \%$.

Kesimpulan. Imunisasi di Kota Sukabumi masih merupakan salah satu upaya yang efektif untuk mencegah terjadinya TB paru pada anak. Sari Pediatri 2018;19(6):321-7

Kata kunci: imunisasi BCG, TB paru anak, tuberkulosis

\section{Correlation between BCG Immunization and Tuberculosis among Children in 2015-2016}

\author{
R. Evi Sofia Riani, Putri Bungsu Machmud*
}

Background. Tuberculosis is still a health problem in the world. In 2014 there's an increasing incidence, prevalence and death due to TB in Indonesia.

Objectives. The aims of study is to know the risk of not being immunized by BCG on the incidence of Pulmonary TB in children in Sukabumi City 2015-2016 after controlled by age, sex, birth weight, exclusive breastfeeding, Neonatal visits, Vitamin A, Mother's job. While the secondary objectives are to identify the status of BCG immunization and incidence of Pulmonary TB in children and the covariat variabels and knowing the risk of not being immunized by BCG. Also knowing the effectiveness of BCG vaccine in Sukabumi City.

Methods. This study used case control design, which the cases and controls are children under 5 years old in Sukabumi City obtained from regular reports of TB program, immunization, KIA and Nutrition at health office in Sukabumi city.

Result. The results of multivariate analysis showed the risk of children not immunized and $\mathrm{KN}=3$ times was 1.13 times higher for pulmonary tuberculosis than the reference. From these results is known that the vaccine efficacy(VE) without interaction is $67 \%$ while the VE with interaction is $82 \%$.

Conclusion. The conclusion of this study is that immunization in Sukabumi City is still effective effort to prevent the incidence of Pulmonary TB in children. Sari Pediatri 2018;19(6):321-7

Keywords: BCG immunization, pulmonary tuberculosis at children, tuberculosis

Alamat korespondensi: Putri Bungsu Machmud. Staf Dinas Kesehatan Kota Sukabumi, Staf pengajar Departemen Epidemiologi FKM-UI, Kampus UI Depok. Jawa Barat. E-mail: putrimachmud@gmail.com 


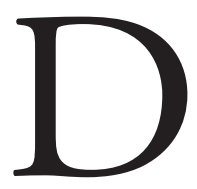
i dunia, angka kejadian tuberkulosis (TB) 9,6 juta orang dan menyebabkan 1,2 juta kematian. Di Indonesia (2014) insiden, prevalensi, bahkan kematian meningkat karena TB . ${ }^{1}$ Menurut WHO, ${ }^{2}$ sekurang 500.000 anak di dunia menderita TB setiap tahun. Menurut Kemenkes RI, ${ }^{2}$ proporsi kasus TB anak dalam batas normal (8-11) \%.

Imunisasi BCG merupakan salah satu upaya preventif pemerintah mencegah kejadian TB (cakupan di atas 90\%). Namun, cakupan menurun di tahun 2014-2015 (masih di bawah 90\%). Vaksin BCG memiliki efektivitas BCG 60\%-80\% protektif terhadap TB pada anak, terutama meningitis. Efektivitas BCG bervariasi tergantung letak geografis. ${ }^{3}$ Berdasarkan penelitian lain efektivitas vaksin BCG bervariasi antara 0\%-80\%, tertinggi $80 \%$ ada di Inggris dan Amerika. Penelitian yang dilakukan oleh Brosch dkk, ${ }^{6}$ menyatakan bahwa strain BCG yang disuntikkan juga berpengaruh terhadap efektivitas vaksin BCG.

Di lain pihak, efektivitas BCG vaksin BCG makin menurun di negara berkembang karena meningkatnya strain baru, Mycobacterium Tuberculosis (Mtb) sehingga vaksin BCG belum mampu mengontrol perkembangan penyakit TB dan dibutuhkan vaksin baru yang lebih efektif. ${ }^{6}$

Kota Sukabumi merupakan salah satu wilayah di Jawa Barat dengan angka kejadian TB yang tinggi. Berdasarkan laporan tahunan bidang P2PL Dinas Kesehatan Kota Sukabumi tahun 2015, total jumlah kasus TB tahun 2015 adalah 932 kasus, 318 kasus baru BTA+ dan 208 kasus TB pada anak. Sementara cakupan imunisasi BCG tahun 2015 tercatat sudah mencapai target Nasional $(98 \%)^{4}$ menggunakan vaksin produksi Biofarma (strain BCG Pasteur).

Dari kondisi tersebut, peneliti tertarik untuk mengetahui tingkat risiko tidak diimunisasi BCG terhadap kejadian TB Paru pada anak di Kota Sukabumi sebelum dan sesudah dikontrol variabel confounding dan atau variabel interaksinya jika ada serta mendapatkan efektivitas vaksin BCG di Kota Sukabumi.

\section{Metode}

Penelitian ini merupakan studi epidemiologi yang bersifat observasional. Desain penelitian adalah studi kasus kontrol (retrospektif) dengan populasi anak usia 0-5 tahun di Kota Sukabumi. Sampel adalah anak umur 6 bulan - 5 tahun dengan kriteria inklusi adalah memiliki kelengkapan data terkait variabel yang dibutuhkan dan berdomisili di Kota Sukabumi. Kriteria eksklusi adalah anak dengan HIV, gizi buruk dan anak dengan penyakit berat lainnya. Gizi buruk dieksklusi untuk menghindari temporal ambiguity karena kita tidak dapat memastikan mana yang lebih dahulu, kejadian TB yang menyebabkan gizi buruk atau sebaliknya. Selain itu, kasus gizi buruk yang rendah di kota Sukabumi menyebabkan peneliti menjadikan gizi buruk sebagai kriteria eksklusi

Kelompok kasus adalah anak yang telah didignosis TB paru dengan sistem skoring di Kota Sukabumi tahun 2015-2016 dan kelompok kontrol adalah anak yang tidak didiagnosis TB paru dengan sistem skoring di Kota Sukabumi tahun 2015-2016.

Data kasus diambil secara acak dari form TB03 yang kemudian akan dilihat di Form TB01 untuk mengetahui alamat dan nama orangtua. Data kontrol dipilih secara acak berdasarkan alamat rumah kasus (Kelurahan dan RW yang sama dengan kasus). Data untuk variabel independen pada kasus dan kontrol diperoleh dari laporan hasil pelayanan imunisasi, kohort bayi dan balita, laporan program gizi dan kartu ibu hamil. Data yang tidak terdapat dalam laporan tersebut dianggap sebagai tidak lengkap. Dari hasil perhitungan minimal sampel Kelsey diperoleh minimal kasus dan kontrol dengan ratio 1: 3 sebanyak 400 sampel.

Analisis dilakukan dengan menggunakan software STATA versi 13 yang dimulai dari analisis univariat untuk mengetahui karakteristik kasus dan kontrol. Analisis bivariat dilakukan untuk melihat besar risiko tidak diimunisasi BCG terhadap kejadian TB paru sebelum kontrol variabel kovariat dan analisis stratifikasi untuk melihat ada tidaknya variabel interaksi dan perancu. Setelah itu dilakukan analisis multivariat dengan regresi logistik untuk melihat besar risiko tidak diimunisasi BCG terhadap kejadian TB paru setelah dikontrol oleh variabel lainnya. Besaran risiko dari hasil analisis multivariat digunakan untuk menghitung efektivitas vaksin BCG di Kota Sukabumi.

\section{Hasil}

Didapatkan proporsi kasus dan kontrol tidak banyak yang memiliki perbedaan yang bermakna $(<10 \%)$ (Tabel 1). Hanya pada variabel umur, berat badan lahir, dan kunjungan neonatal terdapat perbedaan 
proporsi antara kasus dan kontrol yang mencapai $\geq 10 \%$. Diketahui dari beberapa variabel kovariat ditemukan adanya variabel interaksi, yaitu kunjungan neonatal. Sementara dari beda OR diketahui bahwa dari hasil analisis stratifikasi ini tidak terdapat variabel perancu. Karena variabel kunjungan neonatal sebagai variabel interaksi telah diketahui, dilakukan analisis multivariat dengan memasukkan variabel interaksi ke dalam full model. Dengan menggunakan model Hierarchicall Well Formulated (HWF Model) ditemukan bahwa variabel umur dan berat badan lahir merupakan variabel perancu yang harus dikontrol dalam analisis multivariat .

Tabel 3 menunjukkan bahwa hubungan imunisasi BCG dengan kejadian TB paru pada anak di Kota Sukabumi tahun 2015-2016 berinteraksi dengan variabel kunjungan neonatal dan dikontrol oleh kunjungan neonatal, berat berat badan lahir, dan umur.

Hasil pengukuran efek interaksi didapatkan risk difference (RD) 0,56 (positif /sinergisme). Dari perhitungan $\mathrm{RD}$ dapat disimpulkan bahwa kunjungan neonatal berinteraksi positif, dimana variabel kunjungan neonatal menambah efek imunisasi BCG untuk mencegah TB paru pada anak. Di antara efek interaksi responden yang tidak diimunisasi BCG dan kunjungan neonatal $<3$ kali $(\mathrm{OR}=5,62)$, terdapat efek dasar $(\mathrm{OR}=1)$, efek Imunisasi BCG saja $(\mathrm{OR}=0,13)$ dan efek kunjungan neonatal saja $(\mathrm{OR}=3,96)$ sehingga efek interaksi yang sebenarnya adalah $\mathrm{OR}=0,53$.

Proporsi kejadian TB paru yang diakibatkan adanya interaksi imunisasi BCG dengan kunjungan neonatal adalah $9,4 \%$. Ini berarti bahwa dari semua kejadian TB paru, 9,4\% terjadi karena adanya interaksi antara imunisasi BCG dengan kunjungan neonatal. Perhitungan efektivitas BCG berdasarkan hasil OR, efektivitas vaksin dengan interaksi $\mathrm{OR}=5,62$ sehingga efektivitas vaksin $82 \%$ dan tanpa interaksi $\mathrm{OR}=3,045$ dengan efektivitas vaksin $67 \%$.

Tabel 1. Karakterisik kasus dan kontrol pada hubungan imunisasi BCG dengan kejadian TB paru

\begin{tabular}{|c|c|c|c|c|}
\hline \multirow[t]{2}{*}{ Variabel kovariat } & \multicolumn{2}{|c|}{ Kasus } & \multicolumn{2}{|c|}{ Kontrol } \\
\hline & $\mathrm{N}$ & $\%$ & $\mathrm{~N}$ & $\%$ \\
\hline \multicolumn{5}{|l|}{ Jenis kelamin } \\
\hline Laki-laki & 54 & 54 & 160 & 53,3 \\
\hline Perempuan & 46 & 46 & 140 & 46.7 \\
\hline \multicolumn{5}{|l|}{ Umur (tahun) } \\
\hline 0 & 6 & 6 & 20 & 6,7 \\
\hline 1 & 44 & 44 & 154 & 51,3 \\
\hline 2 & 42 & 42 & 96 & 32,0 \\
\hline 3 & 3 & 3 & 17 & 5,7 \\
\hline 4 & 5 & 5 & 14 & 4,3 \\
\hline \multicolumn{5}{|c|}{ Berat badan lahir (gram) } \\
\hline$<2500$ & 16 & 16 & 17 & 5,7 \\
\hline$\geq 2500$ & 84 & 84 & 283 & 94,3 \\
\hline \multicolumn{5}{|c|}{ Pemberian ASI eksklusif } \\
\hline Tidak & 69 & 69 & 195 & 65 \\
\hline $\mathrm{Ya}$ & 31 & 31 & 105 & 35 \\
\hline \multicolumn{5}{|c|}{ Pemberian vitamin A } \\
\hline $\mathrm{Ya}$ & 24 & 24 & 67 & 22,3 \\
\hline Tidak & 76 & 76 & 233 & 77,7 \\
\hline \multicolumn{5}{|c|}{ Kunjungan neonatal } \\
\hline 0 & 8 & 8 & 2 & 0,7 \\
\hline 1 & 55 & 55 & 130 & 43,3 \\
\hline 2 & 0 & 0 & 5 & 1,7 \\
\hline 3 & 37 & 37 & 163 & 54,3 \\
\hline \multicolumn{5}{|l|}{ Pendidikan ibu } \\
\hline Rendah & 53 & 53 & 162 & 54 \\
\hline Tinggi & 47 & 47 & 138 & 46 \\
\hline \multicolumn{5}{|l|}{ Pekerjaan ibu } \\
\hline Bekerja & 36 & 36 & 79 & 26,3 \\
\hline Tidak bekerja & 64 & 64 & 221 & 73,7 \\
\hline
\end{tabular}


Tabel 2. Hubungan imunisasi BCG dengan kejadian TB paru berdasarkan starata variabel lainnya

\begin{tabular}{|c|c|c|c|c|c|c|c|c|}
\hline \multirow[t]{2}{*}{ Variabel } & \multirow[t]{2}{*}{ Status imunisasi BCG } & \multicolumn{2}{|c|}{ Kejadian TB paru } & \multirow{2}{*}{$\begin{array}{c}\mathrm{OR} \\
(95 \% \mathrm{CI})\end{array}$} & \multirow{2}{*}{$\begin{array}{l}\text { OR MH } \\
95 \% \text { CI }\end{array}$} & \multirow{2}{*}{$\begin{array}{c}\text { OR Crude } \\
95 \% \text { CI }\end{array}$} & \multirow[t]{2}{*}{$\mathrm{p}$} & \multirow{2}{*}{$\begin{array}{c}\text { Beda } \\
\text { OR }\end{array}$} \\
\hline & & $\begin{array}{c}\text { Kasus } \\
\mathrm{N}\end{array}$ & $\begin{array}{c}\text { Kontrol } \\
\mathrm{N}\end{array}$ & & & & & \\
\hline \multicolumn{9}{|l|}{ Umur (tahun) } \\
\hline \multirow[t]{2}{*}{$>2$} & Tidak & 3 & 8 & 1,650 & 3,276 & 3,270 & 0,386 & 0,18 \\
\hline & Ya & 5 & 22 & $(0,319-8,542)$ & $(2,022-5,307)$ & $(2,018-5,297)$ & & \\
\hline \multirow[t]{2}{*}{$\leq 2$} & Tidak & 43 & 54 & 3,510 & & & & \\
\hline & Ya & 49 & 216 & $(2,115-5,826)$ & & & & \\
\hline \multicolumn{9}{|l|}{ Jenis kelamin } \\
\hline \multirow[t]{3}{*}{ Perempuan } & Tidak & 18 & 31 & 2,260 & 3,252 & 3,270 & & \\
\hline & & & & $(1,107-4,616)$ & $(2,010-5,263)$ & $(2,018-5,297)$ & 0,168 & 0,55 \\
\hline & Ya & 28 & 109 & & & & & \\
\hline \multirow[t]{2}{*}{ Laki-laki } & Tidak & 28 & 31 & 4,481 & & & & \\
\hline & Ya & 26 & 129 & $(2,311-8,691)$ & & & & \\
\hline \multicolumn{9}{|l|}{ Berat badan lahir } \\
\hline \multirow[t]{3}{*}{$\geq 2500 \mathrm{gr}$} & Tidak & 40 & 57 & 3,604 & 3,212 & 3,270 & & \\
\hline & & & & $(2,148-6,047)$ & $(1,972-5,231)$ & $(2,018-5,297)$ & 0,24 & 1,8 \\
\hline & Ya & 44 & 226 & & & & & \\
\hline \multirow[t]{3}{*}{$<2500$} & Tidak & 6 & 5 & 1,440 & & & & \\
\hline & & & & $(0,337-6,161)$ & & & & \\
\hline & Ya & 10 & 12 & & & & & \\
\hline \multicolumn{9}{|c|}{ Pemberian ASI eksklusif } \\
\hline \multirow[t]{2}{*}{ ASI } & Tidak & 11 & 11 & 4,700 & 3,261 & 3,270 & 0,339 & 0,18 \\
\hline & Ya & 20 & 94 & $(2,179-12,338)$ & $(1,995-5,329)$ & $(2,018-5,297)$ & & \\
\hline \multirow[t]{2}{*}{ Tidak ASI } & Tidak & 35 & 51 & 2,907 & & & & \\
\hline & Ya & 34 & 144 & $(1,644-5,139)$ & & & & \\
\hline \multicolumn{9}{|c|}{ Pemberian vitamin A } \\
\hline Vit. A & Tidak & 32 & 47 & 2,878 & 3,268 & 3,270 & 0,368 & 0,06 \\
\hline & Ya & 44 & 186 & $(1,650-5,021)$ & $(2,016-5,299)$ & $(2,018-5,297)$ & & \\
\hline Tidak vit. A & Tidak & 14 & 15 & 4,853 & & & & \\
\hline & & & & $(1,796-5,297)$ & & & & \\
\hline & Ya & 10 & 152 & & & & & \\
\hline Kunjungan neon & & & & & & & & \\
\hline 3 kali & Tidak & 9 & 33 & 1,266 & & & 0,007 & 0,2 \\
\hline & & & & $(0,545-2,941)$ & 3,079 & 3,270 & & \\
\hline & Ya & 28 & 130 & & $(1,891-5,011)$ & $(2,018-5,297)$ & & \\
\hline$<3$ kali & Tidak & 37 & 29 & 5,3 & & & & \\
\hline & Ya & 26 & 108 & $(2,773-10,129)$ & & & & \\
\hline Pendidikan ibu & & & & & & & & \\
\hline Tinggi & Tidak & 23 & 22 & 5,053 & 3,257 & 3,270 & 0,122 & 0,4 \\
\hline & & & & $(2,432-10,499)$ & $(2,012-5,273)$ & $(2,018-5,297)$ & & \\
\hline & Ya & 24 & 116 & & & & & \\
\hline Rendah & Tidak & 23 & 40 & 2,338 & & & & \\
\hline & Ya & 20 & 112 & $(1,221-4,479)$ & & & & \\
\hline Pekerjaan Ibu & & & & & & & & \\
\hline Tidak bekerja & Tidak & 27 & 47 & 2,072 & & & 0,286 & 0,52 \\
\hline & $\mathrm{Ya}$ & 37 & 174 & $(1,495-4,881)$ & 3,253 & 3,270 & & \\
\hline Bekerja & Tidak & 19 & 15 & 4,769 & $(2,004-5,279)$ & $(2,018-5,297)$ & & \\
\hline & $\mathrm{Ya}$ & 17 & 64 & $(2,012-11,3)$ & & & & \\
\hline
\end{tabular}


Tabel 3. Analisis multivariat hubungan imunisasi BCG dengan kejadian TB paru

\begin{tabular}{lccccc}
\hline & $\beta$ & $\mathrm{p}$ & & \multicolumn{2}{c}{$95 \% \mathrm{CI}$} \\
\cline { 5 - 7 } Variabel & & & OR & & \\
\cline { 5 - 7 } & & & & Lower & Upper \\
\hline Status imunisasi BCG & 0,124 & 0,780 & 1,132 & 0,475 & 2,701 \\
Kunjungan neonatal & 0,091 & 0,766 & 1,096 & 0,601 & 1,998 \\
Berat badan lahir & 1,336 & 0,001 & 3,802 & 1,754 & 8,244 \\
Umur & 0,325 & 0,463 & 1,394 & 0,581 & 3,293 \\
Kunjungan neonatal* Status imunisasi BCG & 1,602 & 0,004 & 4,963 & 1,672 & 14,888 \\
\hline
\end{tabular}

Tabel 4. Besar asosiasi pada variabel interaksi

\begin{tabular}{lcc}
\hline Variabel & Perhitungan & OR \\
\hline Tidak imunisasi BCG, kunjungan neonatal $<3$ kali & $\operatorname{Exp}(0,124)(1)+(1,602)(1)$ & 5,62 \\
Tidak imunisasi BCG, kunjungan neonatal $=3$ & $\operatorname{Exp}(0,124)(1)+(1,602)(0)$ & 1,13 \\
Imunisasi BCG, kunjungan neonatal $<3$ kali & $\operatorname{Exp}(0,124)(0)+(1,602)(1)$ & 4,96 \\
Imunisasi BCG, kunjungan neonatal $=3$ & $\operatorname{Exp}(0,124)(0)+(1,602)(0)$ & 1 \\
\hline
\end{tabular}

\section{Pembahasan}

Distribusi kasus dan kontrol pada beberapa variabel tidak menunjukkan perbedaan. Namun, beberapa variabel menunjukkan perbedaan, yaitu pada variabel kunjungan neonatal $(\mathrm{KN})$, responden di kelompok kontrol lebih banyak (54,3\%) dengan KN 3 kali sedangkan pada kelompok kasus lebih banyak (55\%) dengan KN 1 kali. Begitu pula pada responden yang memiliki berat badan <2500 gram, lebih banyak terdapat pada kelompok kasus (16\%) dibandingkan dengan pada kelompok kontrol (5,7\%). Hal tersebut sesuai dengan hasil penelitian Setiawan ${ }^{8}$ yang melaporkan bahwa berat badan lahir merupakan faktor risiko terhadap kejadian TB paru pada balita.

Hasil analisis bivariat diketahui bahwa terdapat hubungan antara imunisasi BCG dengan kejadian TB paru pada anak di kota sukabumi. Penelitian ini sejalan dengan penelitian Rosandali dkk, ${ }^{11}$ Pernanda $^{12}$ dan Setiawan ${ }^{8}$ yang melaporkan tingkat risiko tidak di imunisasi BCG terhadap kejadian TB paru. Hasil analisis stratifikasi menunjukkan bahwa variabel umur, jenis kelamin, berat badan lahir, kunjungan neonatal, pemberian ASI eksklusif, pemberian vitamin A, pekerjaan dan pendidikan ibu bukan merupakan variabel perancu. Dengan demikian, hubungan imunisasi BCG dengan kejadian TB paru pada anak di Kota Sukabumi tidak rancu. Hasil ini tidak sejalan dengan hasil penelitian di Taiwan ${ }^{11}$ yang melaporkan bahwa jenis kelamin merupakan faktor risiko terhadap infeksi TB. Begitu pula dari hasil penelitian Oktiana ${ }^{21}$ yang melaporkan bahwa ASI merupakan faktor risiko kejadian TB paru.

Hasil analisis stratifikasi menunjukkan adanya variabel interaksi pada hubungan imunisasi BCG dengan kejadian TB paru. Oleh karena itu, efektivitas vaksin BCG di Kota Sukabumi dihitung berdasarkan besar asosiasi tanpa interaksi dan besar asosiasi dengan interaksi yang menghasilkan OR dengan interaksi sebesar $82 \%$ dan OR tanpa interaksi sebesar $67 \%$. Hasil penelitian ini menunjukkan bahwa kunjungan neonatal lengkap/sesuai standar $(\mathrm{KN}=3$ kali) menjadikan efektivitas vaksin BCG lebih tinggi dari jika kunjungan neonatal tidak lengkap/ dilaksanakan sesuai standar. Ini menunjukkan bahwa program pemerintah yang dilaksanakan sesuai standar dapat ikut meningkatkan cakupan program lain yang berhubungan dengan sasaran yang sama, yaitu ibu dan anak. Hasil penelitian terdahulu menyatakan bahwa efektifitas vaksin BCG di Indonesia masih rendah (0\%-80\%) tergantung genetis dan letak gografis. ${ }^{6}$ Begitu pula dengan hasil penelitian Barreto $\mathrm{dkk}^{15}$ di Brazil tahun 2011 dilaporkan bahwa efektivitas vaksin BCG secara keseluruhan adalah 12\% dengan efektivitas terendah di Manaus sebesar 1\%. 
Efektivitas vaksin yang tinggi terjadi karena masih adanya potensi variabel perancu yang belum dikontrol, seperti kondisi lingkungan fisik responden. Simbolon, ${ }^{16}$ melaporkan bahwa luas ventilasi rumah kurang dari $10 \%$ luas lantai memiliki risiko tinggi untuk terkena TB paru. Begitu pula jika cahaya matahari tidak masuk ke rumah berisiko tinggi terhadap kejadian TB paru. Penelitian terdahulu di Indonesia mengenai efektivitas vaksin BCG pernah dilakukan oleh Putrali ${ }^{27}$ dan Gunadi ${ }^{26}$ pada anak umur 0-12 tahun yang didiagnosis TB. Efektifitas imunisasi BCG untuk melindungi anak dari semua jenis TB adalah 37\%. Sedangkan untuk TB berat efektivitas nya sebesar $66 \%$. Hasil meta analisis yang dilakukan oleh Graham dkk, ${ }^{17}$ menyatakan bahwa rata-rata efektivitas vaksin sebesar 50\% akan mengurangi risiko terjadinya TB.

\section{Kesimpulan}

Hasil analisis multivariat menunjukkan bahwa kunjungan neonatal merupakan variabel yang berinteraksi dengan imunisasi BCG dalam memengaruhi kejadian TB paru pada anak di Kota Sukabumi dan interaksi imunisasi BCG dengan kunjungan neonatal meningkatkan efektivitas vaksin BCG di Kota Sukabumi.

\section{Daftar pustaka}

1. Kementrian Kesehatan RI. Jakarta. Pedoman nasional pengendalian tuberkulosis tahun 2014. Kemkes RI;2015.

2. Kementrian Kesehatan RI. Profil Kesehatan Indonesia tahun 2016. Kementrian Kesehatan RI 2017.

3. Roy A, Harris RJ, Rodrigues LC, dkk. Effect of BCG vaccination against Mycobacterium tuberculosis infection in children: systematic review and meta-analysis. BMJ 2014;349:g4643. doi: https://doi.org/10.1136/bmj.g4643.

4. Kementrian Kesehatan RI. Profil kesehatan Indonesia tahun 2015. Kemkes RI; 2016.

5. Pope E, Krafchik BR, Macarthur C, Stempak D, Stephens $\mathrm{D}$, Weinstein M, Baruchel S. Oral versus high-dose pulse corticosteroids for problematic infantile hemangiomas: A randomized, controlled trial. Pediatrics 2007;119:e1239-47.

6. Brosch R, Gordon SV, Garnier T, Eiglmeier K, Frigui W, Valenti P, dkk. Genome plasticity of BCG and impact on vaccine efficacy. Proc Natl Acad Sci 2007;104:5596-601.
7. Surbakti CA, Novitawati S, Bill M. Inovasi vaksin DNA heat shock protein 65 (hsp65) dengan ubiquitin terenkapsulasi nanopartikel PLGA sebagai terapi preventif dan kuratif tuberkulosis. Cermin Dunia Kedokteran 2016;43:230-4.

8. Setiawan, Yudhi. Hubungan status imunisasi BCG dengan kejadian tuberkulosis pada Balita di Rumah Sakit Umum Pusat Dr. Mohammad Hoesin Palembang tahun 2008-2009. Fakultas Kesehatan Masyarakat Universitas Indonesia, 2009.

9. Rachim R. Hubungan pemberian imunisasi BCG dengan kejadian tuberkulosis pada anak di Puskesmas Pandian Kabupaten Sumenep 2014, disertasi. Malang: Universitas Muhammadiyah Malang, 2014.

10. Dinas Kesehatan Kota Sukabumi. Laporan tahunan Bidang P2PL Dinas Kesehatan Kota Sukabumi tahun 2015. Dinas Kesehatan Kota Sukabumi; 2015.

11. Rosandali F, Aziz R, Suharti N. Hubungan antara pembentukan scar vaksin BCG dan kejadian infeksi tuberkulosis. Jurnal Kesehatan Andalas 2016;5:1-5.

12. Pernanda $S$. Hubungan antara pemberian imunisasi BCG dengan kejadian tuberkulosis paru pada balita di RSUD Panembahan Senopati Bantul, skripsi. Ilmu Keperawatan Respati, 2013.

13. Susanto CK, Wahani A, Rompis J. Hubungan pemberian imunisasi BCG dengan kejadian TB paru pada anak di Puskesmas Tuminting periode Januari 2012-Juni 2012. E-Clinic 2016;4:1-6.

14. Rohayu N, Yusran S. Analisis faktor risiko kejadian TB paru BTA positif pada masyarakat pesisir di wilayah kerja Puskesmas Kadatua Kabupaten Buton Selatan. JIMKESMAS 2016;1:21-7.

15. Barreto ML, Pereira SM, Pilger D, Cruz AA, Cunha SS, Sant'Anna, dkk. Evidence of an effect of BCG revaccination on incidence of tuberculosis in school-aged children in Brazil: second report of the BCG-REVAC clusterrandomised trial. Vaccine 2011;29:4875-7.

16. Simbolon D. Faktor risiko tuberkulosis paru di kabupaten Rejang Lebong. JKesMas Nasional 2007;2:112-9

17. Graham AC. Efficacy of BCG vaccine in the prevention of tuberculosis meta analysis of published literature. JAMA 1994;271:698-702.

18. Kementrian Kesehatan RI. Analisis dan data imunisasi Jakarta 2014. Pusdatin KemKes RI;2015.

19. Kementrian Kesehatan RI. Riset kesehatan dasar tahun 2013. Kemkes RI;2013.

20. Nur A, Marissa N. Riwayat pemberian air susu ibu dengan penyakit infeksi pada anak. JKesmas 2014;9:144-9.

21. Oktiana R. Perbedaan kejadian tuberkulosis pada anak dengan pemberian Asi eksklusif dibandingkan non ASI eksklusif di Balai Besar Kesehatan Paru Masyarakat Surakarta, disertasi. 
Surakarta: Universitas Muhammadiyah Surakarta, 2015.

22. Sukamti S, Riono P. Pelayanan kesehatan neonatal berpengaruh terhadap kematian neonatal di Indonesia. JITek 2015;2:23-7.

23. Saraswati LD, Ginandjar P, Andriyani W. Household contact of pulmonary tuberculosis in Wonogiri District, Central Java Province, Indonesia. In ASEAN/Asian Academic Society International Conference Proceeding Series 2013.

24. Sidhi P, Dadiyanto DW, Suhartono S. Risk factors for positive tuberculin tests in children. Paediatrica Indones 2011; 51:311-5.
25. Tonda M, Handini KD.. Nutritional Status of current relationship with the growth of children born in this Village Sub Catur Tunggal Depok Sleman Yogyakarta. Medika Respati 2013;8:12-7.

26. Gunadi S. Difference in severity of tubercullosis in children with or without a BCG scar. Pediatrica Indones 1985;23:8792.

27. Putrali J. Penelitian efektifitas vaksinasi BCG pada anak di 8 rumah sakit di Jakarta. Medika 1982;10:79-82. 